\title{
Reappraisal of Rhamdia branneri Haseman, 1911 and $R$. voulezi Haseman, 1911 (Siluriformes: Heptapteridae) from the rio Iguaçu with notes on their morphometry and karyotype
}

\author{
Julio Cesar Garavello ${ }^{1}$ and Oscar Akio Shibatta ${ }^{2}$
}

\begin{abstract}
The species Rhamdia branneri Haseman, 1911 and the subspecies Rhamdia branneri voulezi Haseman, 1911 from rio Iguaçu are currently recognized as synonyms of Rhamdia quelen (Quoy \& Gaimard, 1824). However, recent karyotype and ecomorphology studies distinguish R. branneri and R. voulezi as different species. Examination of Rhamdia populations from rio Iguaçu, including type specimens, together with other congeners from rio Tibagi, allowed to properly reexamine the situation of these Haseman's taxa and references given to Rhamdia in the Iguaçu. The species $R$. branneri and $R$. voulezi have strong serrae with large basis on both margins of the pectoral-fin spine, uncommon in the remaining species of Rhamdia and different from the fine serrate margins of the pectoral spine of $R$. quelen; a regular dorsal profile, slightly curved between supraoccipital and dorsal fin; with dorsal darkbrown or light-gray coloration along body, abdomen pale, without profuse small black spots, common in populations of the upper Paraná species and the type-material of $R$. quelen. Also the following morphometric characters discriminate these species: Rhamdia voulezi, adipose fin elongate; smaller distance between dorsal and adipose fin; smaller length between adipose fin to base of caudal fin and smaller distance from posterior margin of eye to opercular border. Rhamdia branneri, larger distance from dorsal and adipose fins; deeper caudal peduncle; higher trunk depth in the vertical distance through adipose, between pelvic and anal fins; larger scapular bridge; shorter maxillary barbel; shorter external mental barbel; shorter interorbital distance; shorter length of dorsal fin basis and shorter adipose-fin base length. A PCA between the populations of Rhamdia from Iguaçu and a population from rio Tibagi, upper Paraná basin, discriminates the population from Tibagi on basis of dorsal to adipose fin distance, dorsal-fin spine length, maxillary barbel length, eye diameter, and pectoral-fin spine length. This morphometric study allied to the karyotype known differences suggest $R$. branneri and $R$. voulezi as valid species. The complex state of $R$. quelen with the neotype recently designated from rio Samiria recommend new studies on basis of molecular genetics and provision of the names $R$. branneri and $R$. voulezi in the Iguaçu basin.
\end{abstract}

A espécie Rhamdia branneri Haseman, 1911 e sua subespécie Rhamdia branneri voulezi Haseman, 1911 são atualmente consideradas sinônimos de Rhamdia quelen (Quoy \& Gaimard, 1824). Recentemente, estudos de cariótipos e de ecomorfologia distinguiram $R$. branneri $\mathrm{e}$. voulezi em espécies distintas. Exame de populações de Rhamdia do rio Iguaçu, incluindo espécimes-tipo, em conjunto com outras congêneres do rio Tibagi, permitiu reexaminar apropriadamente a situação destas espécies de Haseman e das referências dadas ao gênero Rhamdia para a bacia do rio Iguaçu. Rhamdia branneri e $R$. voulezi diferem de outras espécies de Rhamdia do rio Iguaçu por possuírem ambas as bordas do raio indiviso peitoral fortemente serrada com unidades rombudas, diferentemente da delicada serra do espinho peitoral de R. quelen; combinam o perfil dorsal em suave curva regular, levemente convexo entre o supraoccipital e a nadadeira dorsal e o padrão de colorido marrom escuro ou cinza claro dorsal com abdome pálido, sem qualquer vestígio de colorido densamente pintalgado de negro, comum em outras espécies de Rhamdia da bacia do alto Paraná e ao material tipo de $R$. quelen. Adicionalmente, as seguintes características discriminam estas espécies: Rhamdia voulezi, nadadeira adiposa alongada; menor distância entre as nadadeiras dorsal e adiposa; menor comprimento entre a nadadeira adiposa e a base da nadadeira caudal e menor distância entre a margem posterior da órbita e a margem do opérculo. Rhamdia branneri, maior distância da nadadeira dorsal à adiposa; maior altura do pedúnculo caudal; maior altura do tronco na vertical que passa pela nadadeira adiposa e entre as nadadeiras ventral e anal; maior largura da cintura escapular; menor comprimento do barbilhão maxilar; menor comprimento do barbilhão mentoniano externo; menor distância interorbital; menor comprimento da base da nadadeira dorsal e menor comprimento da base da adiposa. Uma análise de componentes principais realizada entre as populações de Rhamdia do rio Iguaçu e uma população do rio Tibagi, bacia do alto rio Paraná, distinguiu a população do Tibagi com base na distância entre a nadadeira dorsal e a adiposa, comprimento do raio indiviso dorsal, comprimento do barbilhão maxilar, diâmetro orbital e comprimento do raio indiviso peitoral. $\mathrm{O}$ estudo morfométrico aliado às diferenças de cariótipo conhecidas sugerem $R$. branneri e $R$. voulezi como espécies válidas. A complexa situação de $R$. quelen, que possui ampla distribuição e com o neótipo recém designado para o rio Samiria, recomenda a realização de novos estudos com base em genética molecular e a manutenção dos nomes $R$. branneri e $R$. voulezi para o rio Iguaçu.

Keywords: Endemism, Ostariophysi, Revision, Taxonomy.

\footnotetext{
${ }^{1}$ Departamento de Ecologia e Biologia Evolutiva, CCBS, Universidade Federal de São Carlos, Rodovia Washington Luis, km 235, Caixa Postal 676, 13565-905 São Carlos, SP, Brazil. garavelo@ufscar.br (corresponding author)

${ }^{2}$ Departamento de Biologia Animal e Vegetal, Centro de Ciências Biológicas, Universidade Estadual de Londrina, Campus Universitário, Caixa postal 10.001, 86057-970 Londrina, PR, Brazil.shibatta@uel.br
} 


\section{Introduction}

Rhamdia Bleeker, 1858 is recognized by the combination of the following characters proposed by Silfvergrip (1996): three pair of barbels; vomer bone edentulous; double lip fold; posterior process of the fourth parapophysis expanded distally with one large and several smaller indentations; supraoccipital process free from supraneural plate; orbital rim free; adipose fin with free posterior margin, posterior fontanel closed and posterior process of cleithrum (humeral process) well developed. One additional feature that diagnoses Rhamdia is the forked caudal fin with rounded lobes. None of these characters, however, are exclusive to Rhamdia and there is no attempt to test the monophyly of Rhamdia or to determine the synapomorphies that support the genus.

On the other hand, during the last century the genus Rhamdia appeared with 66 described species, as listed by Gosline (1945) and accepted by Mees (1974). Silfvergrip (1996) revised the genus and recognized only 11 valid species, distributed from Mexico to Argentina and confined to the Cis-Andean region of South America as accepted by Bockmann \& Guazelli (2003) and Ferraris (2007). With respect to the Iguaçu Rhamdia, Shibatta \& Garavello (1995) studied populations of this genus in accord that this area perhaps retain exclusive species of Rhamdia. Also Garavello \& Shibatta (2007), Garavello et al. (2012) and Baumgartner et al. (2012), inform the Iguaçu basin as an area of medium endemism with native species inclusive those of Rhamdia.

From this area, Haseman (1911) described Rhamdia branneri, Rhamdia branneri voulezi and identified other sympatric species as Rhamdia quelen (Quoy \& Gaimard, 1824), combining the following characters: supraoccipital longer in R. branneri voulezi compared to R. branneri; head proportionally larger than trunk; and adipose fin and barbels relatively shorter than in $R$. quelen. As originally identified by Haseman, the subspecies $R$. branneri voulezi was distinguished from $R$. branneri on basis in the very elongate post-mentonian barbel that surpass the pectoral-fin insertion, and the long maxillary barbel reaching to adiposefin origin. Silfvergrip (1996) refute the characters utilized by Haseman arguing they are labile and put Haseman's species in the synonymy of $R$. quelen.
Further, Abucarma \& Martins-Santos (2001) studying on Rhamdia karyotypes from Iguaçu, and Garcia et al. (2010) on karyotype evolution trends, origin and differentiation of supernumerary chromosomes in $R$. quelen, favored to reappraise the species of Rhamdia from the rio Iguaçu. Recently, Mise et al. (2013), also in a collection from the Iguaçu, revealed that morphological characters split the species $R$. branneri and $R$. voulezi.

In the present study, collections of Rhamdia undertaken by LISDEBE in the 1980s and NUP in 1990s at rio Iguaçu, allow us to reexamine the populations of Rhamdia from this area on basis of morphometry and karyotype available data. The result herein provided is the reappraisal and redescription of $R$. branneri and $R$. voulezi and the recommendation for the maintenance of these names for the Rhamdia species from Iguaçu basin.

\section{Material and Methods}

The morphometric data were obtained with help of a vernier caliper with $0.05 \mathrm{~mm}$ of precision. The following set of measurements were taken point to point (Fig. 1): standard length (SL); pre-dorsal length (DPD); dorsalfin base length (CBD); dorsal-fin height (AD); dorsal-fin to adipose-fin distance (DDAd); adipose-fin base length (CBAd); adipose-fin to caudal-fin base distance (DAdBC); pre-pelvic length (DPV); pelvic-fin to anal-fin distance (DVA); anal-fin base length (CBA); anal-fin to caudal-fin base distance (DAC); caudal-peduncle depth (APC); trunk depth at vertical through adipose fin between pelvic and anal fins (ATAA); first dorsal-fin ray to first pelvic-fin ray distance (D1RD1RV); first pelvic-fin ray to last dorsal-fin ray distance (D1RVUD); last dorsal-fin ray to first analfin ray distance (DURD1A); pectoral-girdle width (LCE); pectoral-fin spine length (CEP); dorsal-fin spine length (CED); maxillary-barbel length (CBM); external mentalbarbel length (CBME); head length (CC); snout length $(\mathrm{CF})$; eye diameter (DO); eye-operculum distance (DOOp); interorbital distance (DIO); and mouth width (LB). Counts taken included: 1) dorsal-fin rays; 2) pectoral-fin rays; 3) pelvic-fin rays; 4) anal-fin rays; 5) caudal-fin rays; 6) gillrakers on first left branchial arch.
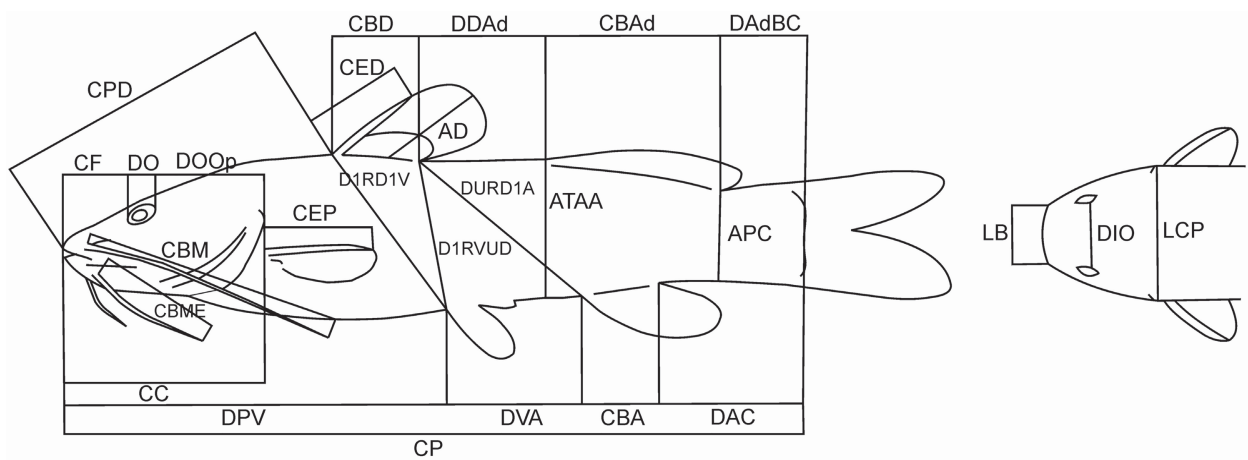

Fig. 1. Diagram of measurements taken from Rhamdia specimens for the principal component analysis. See Materials and Methods for explanation of abbreviations. 
Morphometric analysis. Body proportions were obtained for each character in relation to standard length (SL) except subunits of head that were taken in relation to head length (HL). The principal component analysis (PCA), that included the holotype measurements of $R$. branneri and $R$. voulezi, was applied to discriminate the body forms of these two Rhamdia species from rio Iguaçu. Also these two species were compared with a population of Rhamdia from rio Tibagi of the upper Paraná basin adjacent to the Iguaçu. Patterns of size and shape variation among the morphometric variables listed above were used from the studied samples that were evaluated through PCA, a multivariate statistical procedure designed to summarize major patterns of variation among metric characters. The values for all characters were transformed to logarithms to equalize variances of allometric relationships (Bookstein et al., 1985). The principal component scores for the first axis were plotted to assess patterns of size and shape variation within and among $R$. branneri and $R$. voulezi populations. We investigate the species delimitation of these two species based on distinctive morphology, morphometrics, meristics and coloration to redescribe them. In all these cases, reliable morphometric differentiation requires attention to allometry. Statistical analysis were performed using the statistical program PAST (Hammer et al., 2001).

Institutional abbreviations: LISDEBE, Laboratório de Ictiologia Sistemática do Departamento de Ecologia e Biologia Evolutiva da Universidade Federal de São Carlos, São Carlos; MZUEL, Museu de Zoologia da Universidade Estadual de Londrina, Londrina; NUP, Núcleo de
Pesquisas em Limnologia, Ictiologia e Aquicultura-Coleção Ictiológica, Maringá; CAS-IC, California Academy of Sciences-Ichthyological Collection, San Francisco; FMNH, Field Museum of Natural History, Chicago; NRM, Swedish Museum of Natural History, Stockholm. A large collection of Rhamdia from rio Iguaçu housed in these institutions and listed below was studied and 46 specimens were chosen for morphometric analysis, diagnosis, descriptions and photographs. Main karyotype data were taken from Abucarma \& Martins-Santos (2001), Garcia et al. (2010) and Martinez et al. (2011). The examined type material of $R$. branneri and R. branneri voulezi come from FMNH and that of Rhamdia quelen from NRM.

\section{Results}

\section{Rhamdia branneri Haseman, 1911}

(Figs. 2-4)

Rhamdia branneri Haseman, 1911: 377 pl. LXXV; Creek of rio Iguassú (current Iguaçu), near Serrinha, Paraná State, Brazil; -Gosline, 1945: 36 (literature compilation); -Fowler, 1954: 558 (literature compilation); -Ibarra \& Stewart, 1987: 74 (literature compilation); -Severi \& Cordeiro, 1994: 67 fig. (literature compilation); -Garavello et al., 1997: 76 (citation); -Abucarma \& Martins-Santos, 2001: 300 (cytogenetic description); -Baumgartner et al., 2012:134 (citation).

Rhamdia sebae (non Cuvier, 1829): Severi \& Cordeiro, 1994: 69 (literature compilation).

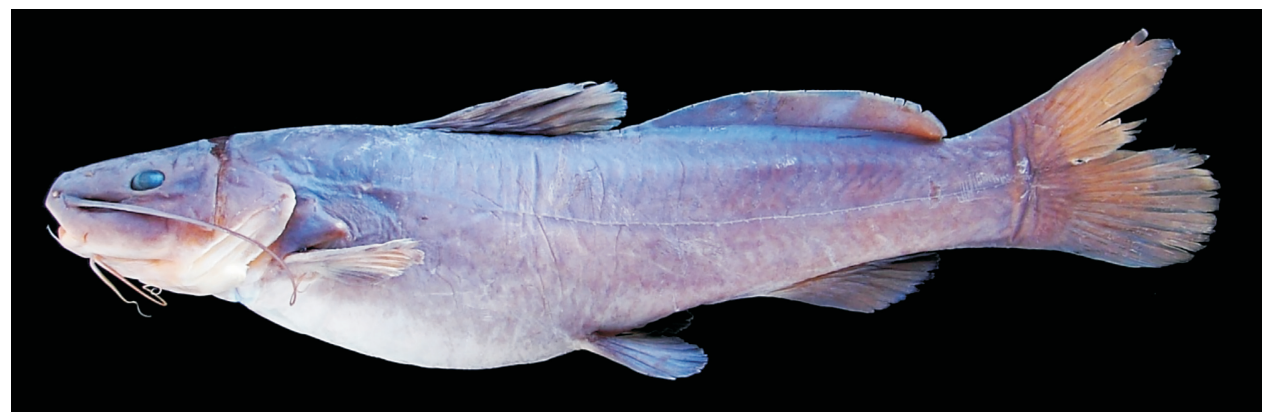

Fig. 2. Lateral view of Rhamdia branneri, LISDEBE 5534, 228.5 mm SL, Brazil, Paraná, rio Timbó, Colônia São Pedro.

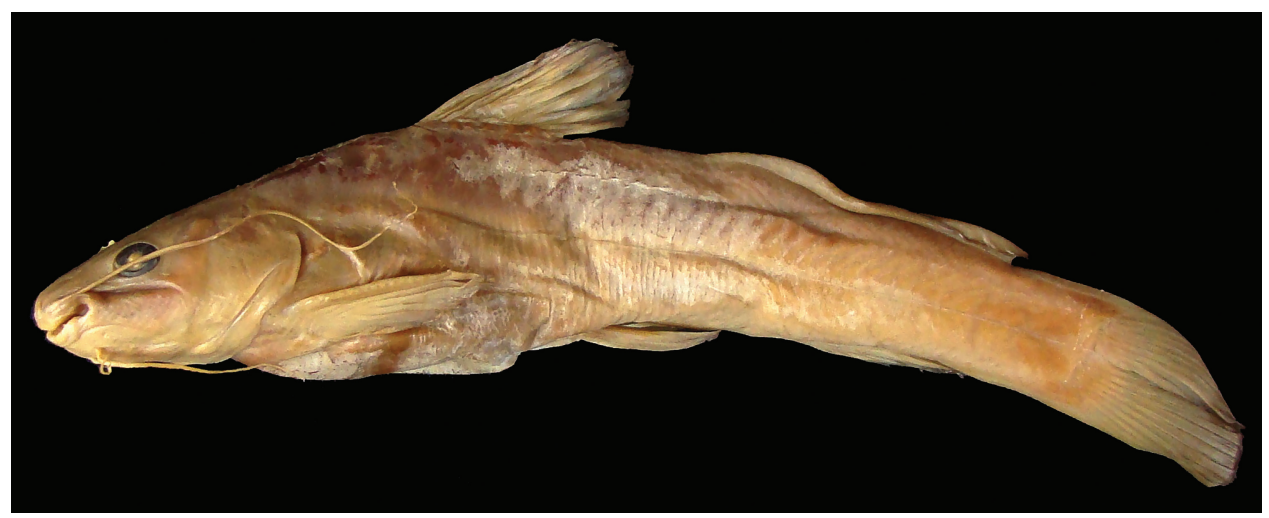

Fig. 3. Lateral view of paratype of Rhamdia branneri, FMNH 54237, 100.0 mm SL, Brazil, Paraná, Serrinha, rio Iguaçu. 


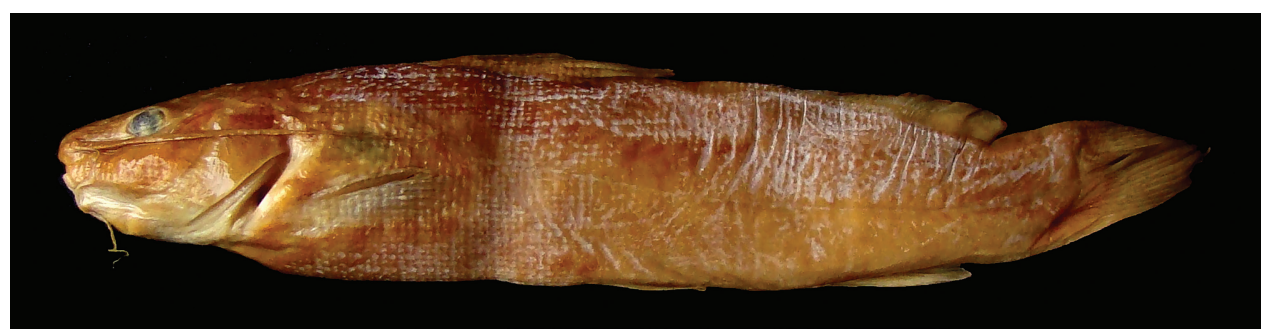

Fig. 4. Lateral view of holotype of Rhamdia branneri, FMNH 54235, 100.3 mm SL, Brazil, Paraná, Serrinha, rio Iguaçu.

Diagnosis. Rhamdia branneri differs from the remaining Rhamdia species, with exception of $R$. voulezi, and Rhamdia cf. quelen from rio Tibagi by having both sides anterior and posterior of the pectoral-fin spine serrate in large dents ( $v s$. slightly serrate in fine dents in Rhamdia cf. quelen). Rhamdia branneri is also distinct by its dorsal-fin length not reaching the origin of the adipose fin when adpressed (vs. adpressed dorsal fin reaching adipose-fin origin in $R$. voulezi and $R$. cf. quelen); maxillary barbel short not reaching the origin of adipose fin ( $v s$. maxillary barbel long, surpassing adipose fin origin in $R$. voulezi and longer than the SL in $R$. cf. quelen); $R$. branneri dorsal profile straight between the snout and supraoccipital process and convex from this point to the dorsal fin insertion (vs. dorsal profile almost straight from tip of snout to dorsal-fin insertion in $R$. voulezi and $R$. cf. quelen). Ground color of preserved $R$. branneri specimens dark or light gray with few large spots and without small black dots over trunk ( $v s$. ground color grayish on dorsum to light orange on abdomen in $R$. voulezi and dark brown spotted in $R$. cf. quelen); dorsal-fin without a hyaline horizontal stripe immediately dorsal to base ( $v s$. a hyaline horizontal stripe higher to base of dorsal fin in $R$. voulezi and $R$. cf. quelen). Differs in corporal proportions from $R$. voulezi in the higher distance between dorsal and adipose fins; higher distance between adipose ending and caudal fin base; higher distance between orbit and opercular bone and larger scapular bridge width; $R$. branneri also differs in chromosome number and morphology: $2 \mathrm{n}=58-62$ chromosomes, plus one submetacentric B chromosome and multiple NOR system ( $v s$. $2 \mathrm{n}=58-60$ plus one metacentric $\mathrm{B}$ chromosome and a simple nucleolus organizer region (NOR) in $R$. voulezi). Rhamdia branneri differs from $R$. voulezi, R. foina (Müller \& Troschel, 1849 ) and $R$. itacaiunas Silfvergrip, 1996 by having 9-14 gill rakers (mode 10) on the first gill arch (vs. 9-14, 12 in mode in $R$. voulezi; $15-20$ in $R$. foina and 5-7 in $R$. itacaiunas); differs from $R$. laukidi Bleeker, 1858 by having absence of a diagonal light bar from superior corner of operculum to base of pelvic fin; $R$. branneri also differs from $R$. xetequepeque, $R$. jequitinhonha Silfvergrip, 1996, R. muelleri (Günther, $1864)$ and $R$. poeyi Eigenmann \& Eigenmann, 1888 by having shorter orbital diameter: $12.9-17.6 \%$ of HL (vs. 12.1$20.2 \%$ in $R$. voulezi, $30.5-36.9 \%$ in $R$. xetequepeque, $20.4 \%$ in $R$. jequitinhonha, $12.1-27.2 \%$ in $R$. muelleri and $20.1-26.2 \%$ in $R$. poeyi). Rhamdia branneri is further distinguished from $R$. jequitinhonha by their longer caudal peduncle (18.4-21.8\% SL vs. $16.3 \%$ ) and longer interorbital distance: $R$. branneri
$30.1-41.8 \%$ HL (vs. $29.8-39.9 \%$ in $R$. voulezi, $24.2 \%$ in $R$. muelleri) and by its shorter maxillary barbel length: 129.9$213 \%$ in R. branneri (vs. 178.5-374.2\% in R. voulezi, and 73.9$129.0 \%$ in $R$. muelleri). It differs from $R$. poeyi by strong and well developed serrae on both sides of pectoral spine (vs. serrae just on posterior margin of pectoral spine); $R$. branneri also differs by a rounded margin of lower lobe ( $v s$. longer and pointed lower caudal fin lobe in $R$. poeyi).

Description. Morphometric characters of $R$. branneri are summarized in Table 1 and the meristic characters in Table 2. Dorsal profile almost straight from tip of snout to supraoccipital and slight convex from this point to dorsal-fin insertion; body depth at anterior vertical through adipose fin and between pelvic and anal fin shorter than the distance between the ending of dorsal fin insertion and pelvic fin. Distance from dorsal to adipose fin generally shorter than the length of dorsal-fin base. Caudal peduncle depth small nearly7.8-12.0, mean $10.7 \%$ SL. Head almost conic in dorsal view, covered by thick skin, except for eyes with free margin, occipital process covered by thick skin (not visible). Orbit relatively large nearly $12.9-17.6$, mean $15.3 \%$ SL in head length. Upper maxillae elongate longer than dentary; premaxillary dental plate distally semicircular; dental plate of dentary narrowing posteriorly with a gap over the mandibulary symphysis; small teeth nearly of same size in premaxillary and dentary. Maxillary barbel short and depressed reaching dorsal-fin insertion, but not reaching adipose-fin insertion; mental external barbel reaching origin of pectoral-fin base; internal mental barbel not surpassing the gill opening. Posterior cleithral process short. Dorsal-fin spine smooth on both anterior and posterior faces. Pectoralfin elongate, both sides anterior and posterior of the serrate pectoral-fin spine; posterior border of pectoral fin reaching vertical through the first branched dorsal-fin ray; pelvic-fin insertion generally beginning at vertical through the last dorsal-fin ray; pelvic-fin rounded; caudal fin furcated; distal lobes rounded, ventral lobe larger than dorsal.

Color pattern of preserved specimens. Ground color of trunk and abdomen dark gray or light gray with few and sparse large brown spots and without small black dots over trunk and abdomen; ground color light gray. Dorsally light brown; interradial membranes hyaline; dorsal fin without a hyaline horizontal stripe immediately dorsal to base. Remaining fins with nearly the same ground color of body. 
Table 1. Body proportions of Rhamdia branneri and Rhamdia voulezi from the rio Iguaçu. SD = Standard deviation.

\begin{tabular}{|c|c|c|c|c|}
\hline & \multicolumn{2}{|c|}{ Rhamdia branneri $(\mathrm{n}=16)$} & \multicolumn{2}{|c|}{ Rhamdia voulezi $(\mathrm{n}=30)$} \\
\hline & Min.-max. & Mean \pm SD & Min.-max. & Mean \pm SD \\
\hline Standard length $(\mathrm{mm})$ & $150.4-327.8$ & $216.9 \pm 50.98$ & $101.7-350.2$ & $207.6 \pm 61.14$ \\
\hline \multicolumn{5}{|l|}{ Percents of standard length } \\
\hline Head length & $20.5-28.1$ & $25.6 \pm 1.60$ & $24.8-29.0$ & $26.2 \pm 0.93$ \\
\hline Predorsal distance & $33.8-39.9$ & $36.5 \pm 1.44$ & $34.1-39.5$ & $35.9 \pm 1.42$ \\
\hline Dorsal-fin base length & $13.5-18.9$ & $15.7 \pm 1.38$ & $14.3-19.0$ & $16.6 \pm 1.28$ \\
\hline Dorsal fin to adipose fin distance & $7.1-14.5$ & $10.2 \pm 2.45$ & $3.1-8.4$ & $5.9 \pm 1.34$ \\
\hline Adipose-fin base length & $23.8-34.9$ & $30.1 \pm 2.94$ & $18.7-38.8$ & $34.5 \pm 3.53$ \\
\hline Adipose fin to caudal fin distance & $9.5-13.0$ & $11.2 \pm 0.93$ & $8.3-12.0$ & $10.3 \pm 1.01$ \\
\hline Pre-pelvic distance & $47.9-54.8$ & $51.3 \pm 2.09$ & $38.9-82.1$ & $51.2 \pm 6.40$ \\
\hline Pelvic fin to anal fin distance & $18.0-22.3$ & $20.0 \pm 1.20$ & $17.9-22.9$ & $20.5 \pm 1.09$ \\
\hline Anal-fin base length & $10.8-15.3$ & $12.5 \pm 1.10$ & $9.8-16.1$ & $12.2 \pm 1.14$ \\
\hline Anal fin to caudal fin distance & $17.2-20.4$ & $19.4 \pm 0.79$ & $17.1-22.2$ & $19.9 \pm 1.32$ \\
\hline Caudal peduncle depth & $7.8-12.0$ & $10.7 \pm 1.14$ & $9.5-13.2$ & $11.0 \pm 0.94$ \\
\hline Pectoral girdle width & $18.0-22.4$ & $20.1 \pm 0.99$ & $17.4-21.8$ & $20.0 \pm 1.04$ \\
\hline Dorsal-fin spine length & $6.5-9.2$ & $7.6 \pm 0.77$ & $6.9-12.1$ & $8.8 \pm 1.24$ \\
\hline Pectoral-fin spine length & $9.7-15.7$ & $12.0 \pm 1.39$ & $10.7-15.4$ & $13.2 \pm 1.11$ \\
\hline Body depth & $14.5-21.5$ & $17.4 \pm 2.06$ & $15.5-23.5$ & $18.6 \pm 1.89$ \\
\hline \multicolumn{5}{|l|}{ Percents of head length } \\
\hline Snout length & $35.6-47.9$ & $39.9 \pm 2.90$ & $37.0-42.7$ & $40.1 \pm 1.47$ \\
\hline Orbital diameter & $12.9-17.6$ & $15.3 \pm 1.57$ & $12.1-20.2$ & $16.4 \pm 1.95$ \\
\hline Interobital distance & $30.1-41.8$ & $33.7 \pm 3.59$ & $29.8-39.9$ & $35.2 \pm 2.79$ \\
\hline Maxillary barbel length & $128.9-213.3$ & $167.8 \pm 24.17$ & $178.5-374.2$ & $261.3 \pm 53.33$ \\
\hline Mouth width & $40.5-57.1$ & $45.4 \pm 4.15$ & $42.1-57.0$ & $47.1 \pm 3.19$ \\
\hline
\end{tabular}

Table 2. Meristic characters of Rhamdia branneri and R. voulezi.

\begin{tabular}{|c|c|c|c|c|}
\hline & \multicolumn{2}{|c|}{ R. branneri } & \multicolumn{2}{|c|}{ R. voulezi } \\
\hline & Counts & Mode & Counts & Mode \\
\hline 1. Dorsal fin & $\mathrm{I}, 6-8$ & $\mathrm{I}, 6$ & $\mathrm{I}, 6-7$ & $\mathrm{I}, 6$ \\
\hline 2. Pectoral fin & $\mathrm{I}, 7-9$ & $\mathrm{I}, 8$ & $\mathrm{I}, 7-9$ & I,9 \\
\hline 3. Pelvic fin & $\mathrm{I}, 4-5$ & $\mathrm{I}, 5$ & $\mathrm{I}, 5$ & $\mathrm{I}, 5$ \\
\hline 4. Anal fin & i-iii,6-9 & $\mathrm{ii}, 7$ and ii, 8 & ii-v,7-9 & $\mathrm{i}, 8$ \\
\hline 5. Caudal fin & $\mathrm{I}, 6-9 / 8-10, \mathrm{I}$ & $\mathrm{I}, 7 / 9, \mathrm{I}$ & $\mathrm{I}, 6-9 / 8-10, \mathrm{I}$ & $\mathrm{I}, 8$ \\
\hline 6. Gill-rakers on outermost arch & $9-14$ & 10 & $9-14$ & 12 \\
\hline
\end{tabular}

Distribution. Known from the rio Iguaçu, rio Paraná basin in Brazil (Fig. 5).

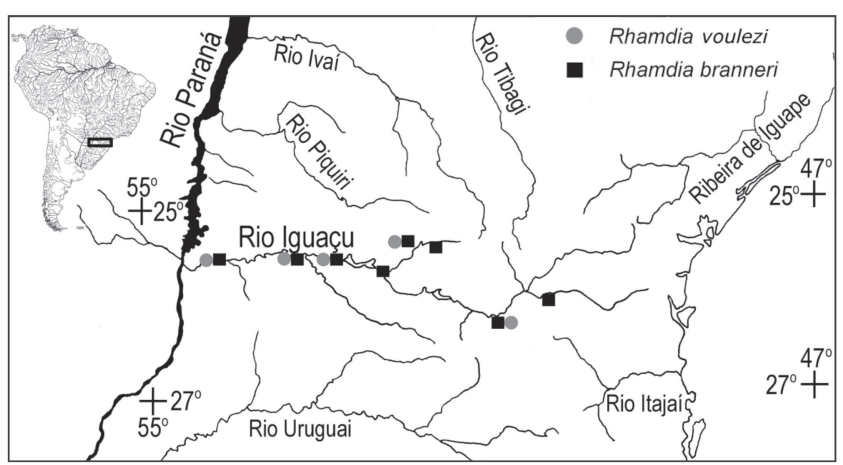

Fig. 5. Geographical distribution of Rhamdia branneri and $R$. voulezi in rio Iguaçu. Each symbol may represent more than one sample.
Material examined. Paraná: FMNH 54235, holotype of Rhamdia branneri, Serrinha, Iguassu (current Iguaçu), J. D. Haseman, 24 Dec 1909; FMNH 54237, 1, paratype of Rhamdia branneri, Iguassu (current Iguaçu), J. D. Haseman, 30 Dec 1909; LISDEBE 5530, 1, rio Negro, under the bridge of BR 116-Rio Negro, collectors of Ichthyology DCB- UFSCar, 2 Apr 1985; LISDEBE 2294, 2, rio Iguaçu, Porto Lupion, collectors of Ichthyology Surehma, Dec 1979-Jan 1980; NUP5715,1, reservoir of Segredo, municipality of Pinhão, border of Mangueirinha, collectors of Nupélia, 19 May 1993, NUP5713,1, Segredo reservoir, municipality of Pinhão, border of Mangueirinha, collectors of Nupélia, 18 Jun 1993; NUP 5719, 2 , rio Iguaçu, down river from hydroelectric Segredo, municipality of Pinhão, border of Mangueirinha, collectors of Nupelia, 7 Sept 1993; NUP 5676, 1, rio Butiá tributary of rio Iguaçu, municipality of Palmas, border of Mangueirinha, collectors of Nupélia, 7 Aug 1993; NUP5720, 2, rio São Pedro, municipality of Pinhão, collectors of Nupélia, 12 Sept 1993; NUP 5718, 2, rio Floresta , municipality 
of Pinhão, collectors of Nupélia, 12-14 Aug 1993; LISDEBE 5531, 3, Porto Lupion, rio Iguaçu, J.C. Garavello \& collectors of Surehma, May 1979; LISDEBE 5532, 1, rio Jordão, tributary of rio Iguaçu at Estância Santa Clara, Candói, J. C. Garavello, 20 Jan 1997; LISDEBE 5533, 1, rio Cavernoso, tributary of rio Iguaçu near Candói, J. C. Garavello \& A. S. Soares, 19-23 Jun 1998. Santa Catarina: Porto União: CAS-SU 62523, 3, rio Iguaçu at Porto União, George S. Myers \& Antenor L. Carvalho, 1944; CAS 62686, 1, rio Iguaçu at Porto União, George S. Myers \& Antenor L. Carvalho, 1944; LISDEBE 5534, 4, rio Timbó, tributary of rio Iguaçu, Colônia São Pedro, J. C. Garavello \& UFSCar collectors, 20-21 Nov 1986; LISDEBE 5535, 1, rio Timbó, tributary of rio Iguaçu, Colônia São Pedro, J C Garavello \& UFSCar collectors, 18-19 Nov 1986.

\section{Rhamdia voulezi Haseman, 1911}

(Figs. 6-7)

Rhamdia branneri voulezi Haseman, 1911: 378, pl. LXXVI; (Porto União da Vitória (current União da Vitória), rio Iguassu (current Iguaçu), Paraná State, Brazil); -Gosline, 1945: 37 (literature compilation); -Fowler, 1954: 558 (literature compilation); -Ibarra \& Stewart, 1987: 74 (literature compilation).

Rhamdia voulezi. -Garavello et al., 1997: 77 (citation); -Abucarma \& Martins-Santos, 2001: 300 (cytogenetic description); -Baumgartner et al., 2012:135 (citation).

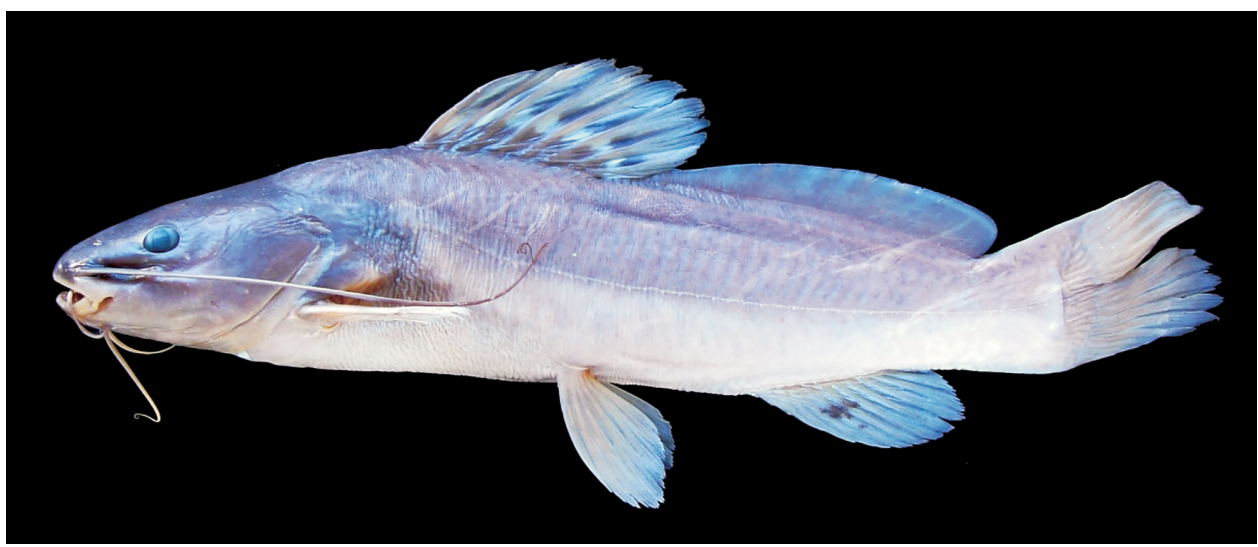

Fig. 6. Lateral view of Rhamdia voulezi, LISDEBE 5529, $214.0 \mathrm{~mm}$ SL, Brazil, Paraná, São José dos Pinhais, rio Iguaçu, marginal pound and lagoons at Torres Avenue, sides of Reserva do Cambuí.

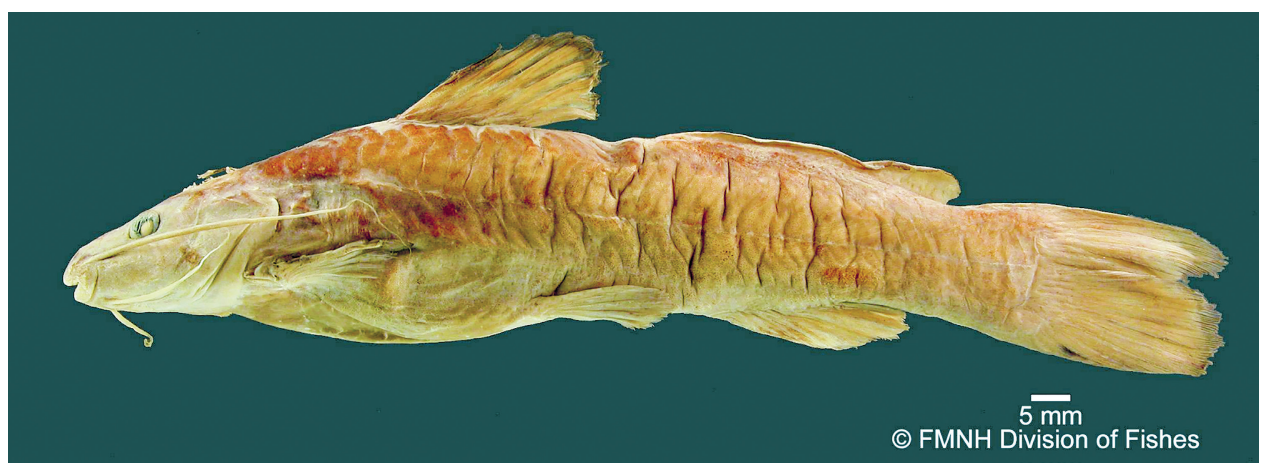

Fig. 7. Lateral view of holotype of Rhamdia branneri voulezi, FMNH 54238, $122.0 \mathrm{~mm}$ SL, Brazil, Paraná, Porto União da Vitória, rio Iguaçu.

Diagnosis. Rhamdia voulezi is distinguished from the remaining Rhamdia species, with exception of $R$. branneri and Rhamdia cf. quelen from rio Tibagi, by having both sides anterior and posterior of the pectoral-fin strong serrate in large dents (vs. slightly serrate in fine dents in Rhamdia cf. quelen). Differ from $R$. branneri by the dorsal profile almost straight from tip of snout, through supraoccipital and to dorsal-fin insertion ( $v s$. dorsal profile straight between the snout and supraoccipital process and convex from this point to the dorsal fin insertion in $R$. branneri). Rhamdia voulezi is also distinct from $R$. branneri by its dorsal-fin length reaching the origin of the adipose fin when adpressed ( $v s$. adpressed dorsal fin not reaching adipose-fin origin in $R$. branneri); maxillary barbel long reaching the origin of adipose fin (vs. maxillary barbel short, not surpassing adipose-fin origin in $R$. branneri; longer than the $\mathrm{SL}$ in $R$. cf. quelen). Ground color of preserved $R$. voulezi specimens grayish on dorsum to light orange on abdomen (vs. dark or light gray with few large spots and without small black dots over trunk in $R$. branneri and dark brown spotted in $R$. cf. quelen). Rhamdia voulezi differs in corporal proportions from $R$. branneri by the longer maxillary barbel (178.5 to 
$374.2 \%$ of HL, mean $=261.3 \%$; vs. 128.9 to $213.3 \%$ of HL, mean $=167.8 \%$ in $R$. branneri); larger interorbital distance ( 29.8 to $39.9 \%$ of HL, mean $35.2 \%$ vs. 30.1 to $41.8 \%$, mean $33.7 \%$ in $R$. branneri); longer dorsal-fin base (14.3 to $19.0 \%$ of SL, mean $=16.6 \%$ vs. 13.5 to $18.9 \%$, mean $=15.7 \%$ in $R$. branneri); and longer adipose fin length (18.7 to $38.8 \%$ of SL, mean $34.5 \% v$ s. 23.8 to $34.9 \%$, mean $30.1 \%$ in $R$. branneri). Rhamdia voulezi also differ in chromosome number and morphology: $2 n=58-60$ plus one metacentric $B$ chromosome and a simple nucleolus organizer region (NOR) (vs. $2 \mathrm{n}=58-62$ chromosomes, plus one submetacentric $\mathrm{B}$ chromosome and multiple NOR system in $R$. branneri). Rhamdia voulezi also differ from $R$. branneri, $R$. foina and $R$. itacaiunas by having 9-14 gill rakers (12 in mode) on the first gill arch (vs. 9-14, 10 in mode in R. branneri, 15-20 in $R$. foina and 5-7 in $R$. itacaiunas); differ from $R$. laukidi by having absence of a diagonal light bar from superior corner of operculum to base of pelvic fin; differ from $R$. branneri, $R$. xetequepeque, $R$. jequitinhonha, $R$. muelleri and $R$. poeyi by having shorter orbital diameter: $R$. voulezi 12.1$20.2 \%$ of HL (vs. $12.9-17.6 \%$ in R. branneri, $30.5-36.9 \%$ in $R$. xetequepeque, $20.4 \%$ in $R$. jequitinhonha, $12.1-27.2 \%$ in $R$. muelleri and $20.1-26.2 \%$ in $R$. poey). Rhamdia voulezi is further distinguished from $R$. jequitinhonha by their longer caudal peduncle (18.4-21.8\% vs. $16.3 \% \mathrm{SL})$ and from $R$. muelleri by the longer interorbital distance $29.8-39.9 \%$ HL in $R$. voulezi (vs. $24.2 \%$ in $R$. muelleri) and shorter maxillary barbel length: $178.5-374.2 \% \mathrm{HL}$ in $R$. voulezi ( $v$ s. $73.9-129.0 \%$ in $R$. muelleri); $R$ poeyi with small serrae of spines on posterior margin of pectoral spine differ from $R$. voulezi with strong and well developed serrae on both sides; $R$. voulezi also differ from $R$. poeyi in caudal fin upper lobe shorter than lower and margin of lower lobe rounded ( $v s$. longer and pointed lower caudal fin lobe in $R$. poeyi).

Description. Morphometric and meristic characters are summarized in Tables 1-2. Dorsal profile almost straight from tip of snout through supraoccipital and to dorsal-fin insertion. Body height between ventral and anal-fin smaller than distance between ending of dorsal fin and anterior insertion of anal fin; caudal peduncle depth small, height near 9.5-13.2, mean $11.0 \%$ SL. Distance from ending dorsal and anterior insertion of adipose fin always shorter than dorsal fin basis; head almost conic, occipital process covered by thick skin. Orbits relatively large, near 12.120.2 , mean $16.4 \%$ HL. Upper maxillae slightly longer than dentary; distal portion of premaxillary dental plate slightly circular; dental plate of mandible slightly decreasing distally and with gap over the mandibulary symphysis; small teeth, almost with same size on premaxillae and dentary. Maxillary barbel flattened, longer and surpassing beginning of adipose-fin insertion. In young specimens, this barbel surpasses anal-fin base; external mental barbel surpassing beginning of pectoral-fin; inner mental barbel surpassing gill opening in juveniles, but not in adults. Posterior cleithral process short. Dorsal-fin spine smooth on both sides. Posterior border of pectoral-fin reaching vertical through the first dorsal-fin branched ray. Pelvic-fin beginning in vertical through anterior or over last ray of dorsal-fin. Anal-fin with rounded distal border. Caudal fin forked; ventral lobe larger than dorsal.

Color pattern of preserved specimens. Ground color generally grayish and with small dispersed black dots; abdomen generally yellowish-orange. Dorsal-fin with a light horizontal line upper to its base; over to this light line the interradial membranes with the same ground color and the branched rays may appear blackish highlighted. Remaining fins with nearly same ground color of body and trunk; interradial membranes hyaline.

Distribution. Known from rio Iguaçu, rio Paraná basin in Brazil (Fig. 5).

Material examined. FMNH 54238, holotype of Rhamdia branneri voulezi, Porto União da Victória, rio Iguassu (current Iguaçu), J. D. Haseman, 24 Dec 1909. Paraná: LISDEBE 2292, 3, rio Iguaçu, Porto Lupion, collectors of Ichthyology Surehma, Dec 1979 - Jan 1980; LISDEBE 2296, 4, rio Iguaçu, Porto Lupion, Surehma collectors, Dec 1979 - Jan 1980; LISDEBE 2293, 1, rio Iguaçu, Porto Lupion, J. C. Garavello \& Surehma collectors, May 1979; LISDEBE 5529, 2, São José dos Pinhais, rio Iguaçu, marginal lagoons at Torres Avenue, beside of Cambuí reserve, UFSCar collectors, 29 Dec 1984; LISDEBE 5527, 1, rio Iguaçu, downriver from the Salto Osorio hydroelectric power dam, municipality of Quedas do Iguaçu, J. C. Garavello, A. S. Soares \& J. C. Soares, 14-17 Jan 1990; LISDEBE 2297, 4, rio Iguaçu, downriver from Salto Santiago hydroelectric power dam, between municipalities of Laranjeiras do Sul and Chopinzinho, J. C. Garavello, A. S. Soares, R. J. Rodrigues, M. J. Veber \& M. M. Paschoa, 5-10 Nov 1990; LISDEBE 2295, 3, rio Cavernoso, tributary of rio Iguaçu, near Candói city, J. C. Garavello \& A. S. Soares, 19-23 Jun 1998; NUP-MU 3893, 1, rio Ocoi, Vila Ipiranga, São Miguel do Iguaçu, Nupélia collectors (2513'S 541'ㄹ), 10 Nov 1988; NUP-MU 2664, 1, riacho na Fazenda Picui, São Miguel do Iguaçu, Nupélia collectors $\left(25^{\circ} 15^{\prime} \mathrm{S}\right.$

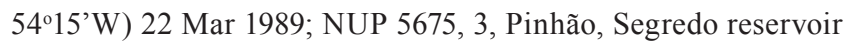
at Mangueirinha border, Nupélia collectors, 10 May 1993; NUP 5674, 7, Pinhão, Segredo reservoir at Mangueirinha municipality border, Nupélia collectors, 17-18 Jun 1993; NUP 5673, 6, Pinhão, Segredo reservoir at Mangueirinha border, Nupélia collectors, 24 Mar 1993; NUP 5678, 3, Palmas, rio Iratim, border with Pinhão and Mangueirinha municipalities, Nupélia collectors, 21 May 1993; NUP 5674, 7, Pinhão, rio São Pedro, Nupélia collectors, 22 Jun 1993; NUP 2673, 1, Pinhão, Foz do Areia reservoir, border with municipality of Bituruna, Nupélia collectors, 1 Jul 2001; NUP 5716, 1, Pinhão, Foz do Areia reservoir, border with municipality of Bituruna, Nupélia collectors, 28 Aug 1993; NUP 5677, 3, Pinhão, Foz do Areia reservoir, border with municipality of Bituruna, Nupélia collectors 12-13 Aug 1993; NUP 5679, 2, Pinhão, Foz do Areia reservoir, border with municipality of Bituruna, Nupélia collectors 12-13 Sep 1993; NUP 5305, 1 of 
29, rio Iguaçu, downriver of Segredo reservoir, municipality of Pinhão at Mangueirinha border, Nupélia collectors, 12 Jul 1993. Santa Catarina: Porto União: LISDEBE 2347, 2, rio Timbó, tributary of rio Iguaçu at colônia São Pedro, J. C. Garavello \& UFSCar collectors, 18-19 Nov 1986; LISDEBE 5528, 1, rio Timbó, tributary of rio Iguaçu, colônia São Pedro, J. C. Garavello \& UFSCar collectors, 19-20 Nov 1986.

\section{Discussion}

The Silfvergrip (1996) decision to include the species Rhamdia branneri and $R$. branneri voulezi under the synonymy of Rhamdia quelen (Quoy \& Gaimard, 1854) contrast with the present study. The examination of specimens from the type series of the neotype of Rhamdia quelen from rio Samiria (Fig. 8) gives opportunity to get in touch with differences between this species and $R$. branneri and $R$. voulezi. They differ concerning to morphology of dorsal and adipose fins, structure and length of mental and maxillary barbels, pigmentation and morphometric traits from the Iguaçu species and the population of Rhamdia cf. quelen from rio Tibagi basin. Also, the examination of the Iguaçu specimens studied by Silfvergrip (1996) revealed that the specimens from São Miguel do Iguaçu (NUP-MU 2664 and NUP-MU 3893) in fact belong to $R$. voulezi. In addition, the examination of the specimens from rio Iguaçu at Porto União, CAS-SU 62523 and CAS-SU 62686 revealed to be $R$. branneri. The pectoral spine double serrate, the karyotype differences and ecomorphological data, as soon as color pattern and morphometric trends herein studied, suggest that $R$. branneri and $R$. voulezi are significantly distinct justifying the present adjustment.

As first consideration, it is important to recognize the analysis of metaphase cells of these species by Abucarma \& Martins-Santos (2001) revealing 58 - 62 (2n) chromosomes for $R$. branneri and 58 - 60 (2n) chromosomes for $R$. voulezi. These authors make clear the variation on karyotypes of Rhamdia from rio Iguaçu within 36 metacentric chromosomes, 14 sub-metacentric chromosomes, 4 subtelocentric chromosomes and 4 acrocentric chromosomes.
They also recognize the presence of two types of $B$ chromosomes: a medium sized B metacentric chromosome and a sub-metacentric chromosome, more frequent in $R$. branneri; 0 to 2 medium sized metacentric and a B submetacentric chromosome in $R$. voulezi. These differences in karyotype of these Iguaçu Rhamdia, including one submetacentric B chromosome in $R$. branneri, vs. one metacentric B chromosome in $R$. voulezi, plus a simple nucleolus organizer region (NOR) in $R$. voulezi, vs. multiple NOR system in $R$. branneri may suggest that differentiation occurred on the karyotype structure of these species. These described chromosomes are considered by the authors as safeguard for inter-specific variation between $R$. branneri and $R$. voulezi.

It is also important to recognize the karyotype description of a Rhamdia quelen population by Moraes et al. (2007) from Bodoquena Plateau, Mato Grosso, Brazil, composed by a diploid number of chromosomes $2 \mathrm{n}=58$ : 36 metacentric; 16 sub-metacentric and 6 sub-telocentric chromosomes. One to three B chromosomes of medium size and the nucleolus organizer region (NOR) situated in terminal region of the shorter arm of the sub-metacentric chromosome pair 20. Also, Martinez et al. (2011) offered a study on three populations of a species defined as Rhamdia quelen from two large Brazilian rivers: Paraná and Araguaia, showing that the diploid number found for the three analyzed populations is 58 stick chromosomes. Following Garcia et al. (2010), "Rhamdia quelen invariably presents $58(2 \mathrm{n})$ chromosomes in all populations that have been analyzed so far. Since $R$. quelen is the most widely species cytogenetically studied among the Heptapteridae, the stability of this diploid number can be regard as characteristic of this species". They observed various karyotype formulae in populations identified as $R$. quelen from the upper and lower Paraná, and from Paraíba do Sul rivers. In both cases the karyotype formula: $36 \mathrm{~m}, 10 \mathrm{sm}$ and 12st (see Garcia et al., 2010) was the most frequent in identifying $R$. quelen populations from Paraná, while $40 \mathrm{~m}$, $10 \mathrm{sm}$ and 8 st was the commonest formula in the Paraiba do Sul populations.

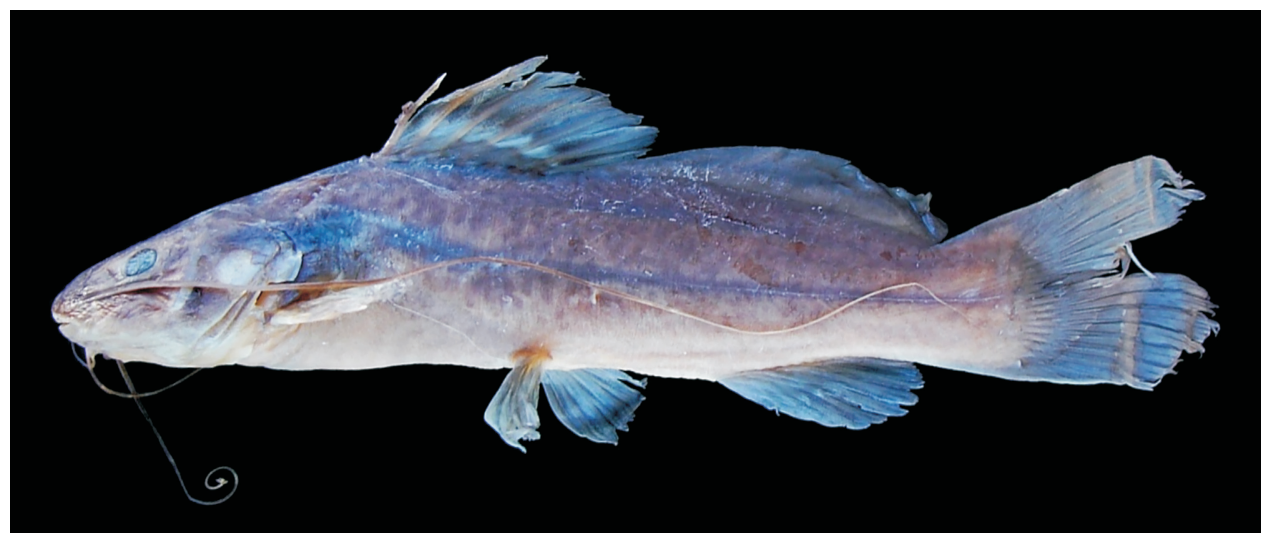

Fig. 8. Lateral view of Rhamdia quelen, neotype series, NRM 33452, 108.3 mm SL, Peru, Loreto, right bank quebradita tributary to rio Samiria between caño Pastos and Hamburgo. 
Perdices et al. (2002) based on sequencing data of mitochondrial genes show that the genus Rhamdia has diverged from other heptapterids very recently, suggesting that Rhamdia is undergoing an initial process of karyotype differentiation, reinforcing their reproductive isolation leading to speciation. For those authors $R$. quelen, sensu Silfvergrip, is polyphyletic under mitochondrial DNA perspective.

As second consideration, concerning to morphometry, Mise et al. (2013) advanced a PCA on populations of $R$. branneri and $R$. voulezi that indicates an obvious segregation between these two species along the first axis of their figure 2. Those authors also revealed that most of the morphologic characters that separate the Rhamdia species from Iguaçu are related to body shape. They clearly discussed that $R$. voulezi can be characterized by having more compressed and less depressed bodies, longer caudal peduncle, wider mouth and larger aspect ratio of the anal fin. On the other hand, $R$. branneri can be characterized by having a higher mouth opening and higher anal fin.

Our morphometric analysis corroborate Mise et al. (2013), concluding that there are two distinct species of Rhamdia in the rio Iguaçu basin. The sheared principal component analysis, herein applied to populations of Rhamdia from Iguaçu, mainly suggest that $R$. branneri and $R$. voulezi may be considered independent specific taxa (Tables 3-4 and Fig. 9). Additionally, a comparison through a principal component analysis between populations of $R$. branneri, $R$. voulezi from Iguaçu versus a population of Rhamdia cf. quelen from rio Tibagi highlighted their differences as showed in Table 5 and Figs. 9-10.

Table 3. Principal component analysis of Rhamdia branneri $(\mathrm{n}=16)$ and $R$. voulezi $(\mathrm{n}=30)$. Sheared Principal Component Analysis and Eigenvalues (Prior to Shearing).

\begin{tabular}{rccc}
\hline & Eingenvalues & Total variance $(\%)$ & Total variance (cumulative $\%)$ \\
\hline 1 & 0.298 & 83.993 & 83.993 \\
2 & 0.036 & 10.204 & 94.197 \\
3 & 0.004 & 1.240 & 95.437 \\
4 & 0.003 & 0.815 & 96.252 \\
5 & 0.003 & 0.727 & 96.978 \\
6 & 0.002 & 0.642 & 97.621 \\
7 & 0.002 & 0.505 & 98.126 \\
8 & 0.002 & 0.424 & 98.549 \\
9 & 0.001 & 0.301 & 98.851 \\
10 & 0.001 & 0.292 & 99.143 \\
11 & 0.001 & 0.223 & 99.366 \\
12 & 0.001 & 0.152 & 99.518 \\
13 & 0.000 & 0.109 & 99.626 \\
14 & 0.000 & 0.099 & 99.725 \\
15 & 0.000 & 0.077 & 99.802 \\
16 & 0.000 & 0.069 & 99.871 \\
17 & 0.000 & 0.049 & 99.920 \\
18 & 0.000 & 0.041 & 99.961 \\
19 & 0.000 & 0.024 & 99.985 \\
20 & 0.000 & 0.015 & 100.000 \\
\hline & & &
\end{tabular}

Table 4. Sheared principal component loadings of the principal component analysis of Rhamdia branneri $(\mathrm{n}=16)$ and $R$. voulezi $(\mathrm{n}=30)$.

\begin{tabular}{lcc}
\hline & PC1 & $\begin{array}{c}\text { Sheared Principal } \\
\text { Component } 2\end{array}$ \\
\hline Head length & 0.225387 & -0.010014 \\
Predorsal distance & 0.232133 & -0.049210 \\
Dorsal-fin base length & 0.218160 & $0.032738(>$ R. voulezi) \\
Dorsal fin to adipose fin distance & 0.170089 & $-0.807027(>$ R. branneri) \\
Adipose-fin base length & 0.223615 & $0.164383(>$ R. voulezi) \\
Adipose fin to caudal fin distance & 0.208639 & -0.128385 \\
Pre-pelvic distance & 0.248891 & -0.070166 \\
Pelvic fin to anal fin distance & 0.231776 & -0.007022 \\
Anal-fin base length & 0.222427 & -0.066667 \\
Anal fin to caudal fin distance & 0.199487 & 0.000423 \\
Caudal peduncle depth & 0.269678 & 0.002440 \\
Pectoral girdle width & 0.245498 & -0.040196 \\
Dorsal-fin spine length & 0.181536 & 0.104746 \\
Pectoral-fin spine length & 0.197812 & 0.074551 \\
Body depth & 0.275806 & 0.048665 \\
Snout length & 0.243877 & $0.007242(>$ R. branneri) \\
Orbital diameter & 0.184111 & 0.071448 \\
Interorbital distance & 0.267512 & $0.076605(>$ R. voulezi) \\
Maxillary barbel length & 0.131916 & $0.508441(>R$. voulezi) \\
Mouth width & 0.238400 & $0.043075(>$ R. branneri) \\
\hline & & \\
& &
\end{tabular}

Table 5. Principal Component loadings between $R$. branneri, $R$. voulezi and Rhamdia cf quelen.

\begin{tabular}{lccc}
\hline & Axis 1 & Axis 2 & Axis 3 \\
\hline Predorsal distance & 0.2293 & -0.04746 & 0.03899 \\
Dorsal-fin base length & 0.222 & 0.01773 & -0.01941 \\
Dorsal fin to adipose fin distance & 0.1867 & -0.774 & 0.1647 \\
Adipose-fin base length & 0.2207 & 0.1554 & 0.02703 \\
Adipose fin to caudal fin distance & 0.2119 & -0.1108 & 0.08364 \\
Pre-pelvic distance & 0.2438 & -0.05166 & 0.1038 \\
Ventral fin to anal fin distance & 0.2256 & 0.002937 & 0.08632 \\
Anal-fin base length & 0.2252 & -0.04737 & -0.01762 \\
Anal fin to caudal fin distance & 0.2008 & 0.006726 & -0.01687 \\
Caudal peduncle depth & 0.2672 & 0.01019 & 0.04614 \\
Snout length & 0.2428 & 0.008378 & -0.008869 \\
Eye diameter & 0.1818 & 0.07199 & 0.3203 \\
Interobital distance & 0.2592 & 0.07494 & 0.02412 \\
Pectoral girdle width & 0.2445 & -0.02995 & 0.04604 \\
Maxillary barbel length & 0.1381 & 0.5729 & 0.3686 \\
Mouth width & 0.2383 & 0.03858 & -0.06656 \\
Dorsal-fin spine length & 0.1909 & 0.09137 & -0.7721 \\
Pectoral-fin spine length & 0.2049 & 0.06548 & -0.3136 \\
Body depth at adipose fin & 0.2709 & 0.05207 & -0.04057 \\
Head length & 0.2241 & -0.006128 & 0.02304 \\
\hline
\end{tabular}




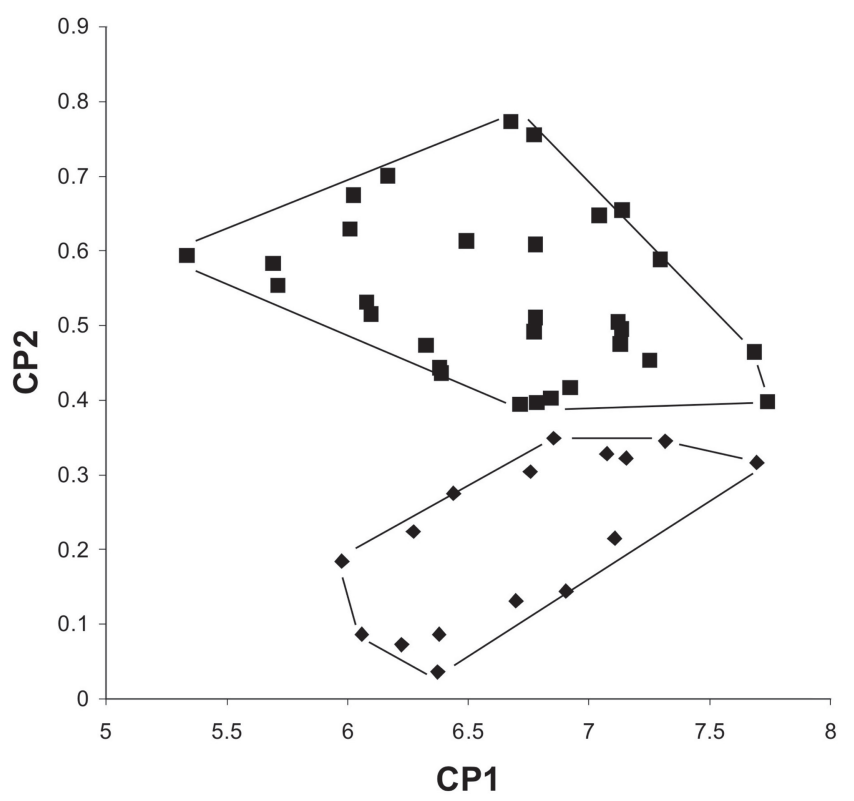

Fig. 9. Scatter plot of combined samples of Rhamdia branneri ( $\mathrm{n}=16$, diamonds) and Rhamdia voulezi $(\mathrm{n}=30$, squares) from rio Iguaçu on the first and second principal component axis.

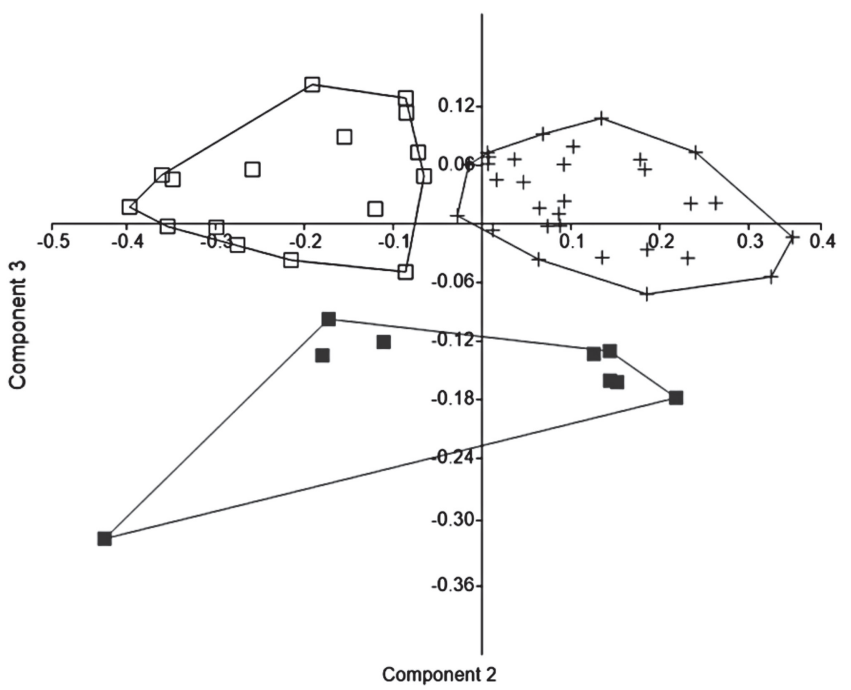

Fig. 10. Scatter plot of combined samples of Rhamdia branneri $(\mathrm{n}=16$, open squares $), R$. voulezi $(\mathrm{n}=30$, crosses $)$ and $R$. cf. quelen. ( $\mathrm{n}=9$, filled squares) from rio Iguaçu and rio Tibagi (Upper Paraná basin) on the second and third principal component axis.

On basis of the accurate examination of the holotype specimens of $R$. branneri and $R$. branneri voulezi, the Iguaçu material studied by Silfvergrip (1996) from CAS and NUP plus a large number of fresh specimens, we conclude that the serrae on both sides of the pectoral spine, the length of the internal and external mental barbels and the length of adipose fin are the main characters to distinguish these species and are in agreement with the pattern established by Haseman for $R$. branneri and $R$. voulezi.
Also R. branneri have the ground color of trunk and abdomen pale brown with rare large dark dots dispersed through body and dorsal-fin without a hyaline horizontal strip immediately dorsal to base. Rhamdia voulezi has the ground color generally gray and without large dispersed black dots; abdomen generally orangish-yellow and the dorsal fin with a light horizontal line dorsal to its base, distinct from $R$. branneri and other species. As a result, the main differential morphometric characters between $R$. branneri and $R$. voulezi that could be seen in Table 4 are: $R$. branneri have smaller interorbital distance, smaller dorsalfin base length, smaller adipose-fin base length, larger mouth and larger snout length; while $R$. voulezi have: larger interorbital distance; larger dorsal-fin base length; larger adipose -fin base length, smaller distance between adpressed dorsal fin and adipose-fin base.

Studies of Shibatta \& Garavello (1995) on morphology, Abucarma \& Martins-Santos (2001), Moraes et al. (2007), Garcia et al. (2003, 2010) and Martinez et al. (2011) on karyotypes, and Mise et al. (2013) on ecomorphology, strength this study on the Rhamdia species from Iguaçu. Given that Perdices et al. (2002) suggest that Rhamdia is undergoing an initial process of karyotype differentiation, it is also important to attempt the molecular data to fulfill gaps of morphology in allowing revisions of the species now identified as Rhamdia quelen sensu Silfvergrip (1996).

Furthermore, the overwhelming endemism verified in the Iguaçu basin, corroborates the distinctiveness of its Rhamdia species. Recent studies on Trichomycterus by Wosiacki \& Garavello (2004), Steindachneridion by Garavello (2005), Pimelodus by Garavello \& Shibatta (2007), Astyanax by Garavello \& Sampaio (2010) and Hypostomus by Garavello et al. (2012) provides strong evidence that the Iguaçu retains exclusive species found nowhere else. Essential to observe that the reference by Severi \& Cordeiro (1994) of Rhamdia sebae, described from Cayenne, Suriname, is inapplicable for any Rhamdia species from Iguaçu.

Finally, the taxonomical simplification proposed by Silfvergrip (1996) when strongly reduced the number of species of Rhamdia recognizing many species as synonym of $R$. quelen (Quoy \& Gaimard, 1824) may be re-evaluated. Perdices et al. (2002) already advanced in this way considering the identification by Silfvergrip of $R$. quelen from Central America a mistake, because there are morphological and molecular evidence to consider the Central America species different from Rhamdia species of South America. So, we agree with Perdices et al. (2002) that genus Rhamdia needs revision under molecular genetic analysis, which may lead to the evaluation of the species actually in synonymy of Rhamdia quelen.

Comparative material examined. Rhamdia quelen: Peru, Loreto: paratypes: NRM 33542, 3, 101.5-122.5 mm SL, right bank quebradita tributary to rio Samiria between caño Pastos and Hamburgo; NRM 16085, 2, 52.3-58.0 mm SL, Amazon 
basin, rio Samiria drainage, left bank quebradita halfway between Hamburgo and Santa Helena. Rhamdia jequitinhonha: Brazil, Minas Gerais: holotype: MZUSP 38.630, $160.9 \mathrm{~mm}$ SL, Santa Rita, rio Araçuai; MZUEL 3617, 2, São Gonçalo do Rio Pardo, rio Preto, rio Jequitinhonha basin, Parque Estadual Rio Preto. Rhamdia foina: Brazil, Roraima: INPA 7988, 2 , 113.2-122.5 mm SL, rio Branco drainage, rio Uraricoera, Ilha de Maracá, furo de Maracá. Brazil, Pará: INPA 7967, 2, 91.897.4 mm SL, Oriximiná, rio Trombetas, montante CPT; INPA 7973, 1, 84.3 mm SL, rio Mapuera, Cachoeira Porteira, last rapid before rio Trombetas. Rhamdia cf. quelen: Brazil, Paraná: Upper Paraná: rio Tibagi: MZUEL 1587, 1, rio Iapó, tributary of Tibagi; MZUEL 1522, 1, Londrina; MZUEL 1034, 2, Londrina; MZUEL 3686, 1, Ponta Grossa; MZUEL 2, 4, Ipiranga; MZUEL 4, 3, Ipiranga; MZUEL 1670, 1, Assaí; MZUEL 8, 1, Jataizinho; MZUEL 5, 2, Uvaia; MZUEL 6, 3, Telêmaco Borba; MZUEL 7, 1, Telêmaco Borba.

\section{Acknowledgements}

We would express our sincere thanks to the NUPÉLIA researchers and collectors, especially to Angelo A. Agostinho, Carla S. Pavanelli and Harumi I. Suzuki, for their continuous interest in the Iguaçu ichthyofauna and loan of specimens. For loan of type-specimens we thanks to Sven Kullander (SMNH); Mark Weastnet, Marianne Rogers and Kevin Swagel (FMNH); Heraldo A. Britski, Osvaldo T. Oyakawa and José L. de Figueiredo (MZUSP) and David Catania (CAS). Alexandre K. de Oliveira (LISDEBE) helped with manuscript revision, photographs and map. Thanks to Anders Silfvergrip, Mark H. Sabaj and José L. Birindelli for their criticism and suggestions. Jose M. M. Gomes (Surehma), Airton S. Soares, José C. Soares and Marcel M. Paschoa (in memoriam) (UFSCar) and Mario L. Orsi (ECPUEL) helped with the field work. Thanks to Marcelo S. Rocha for photographs and information about Rhamdia foina. The authors are grateful to Conselho Nacional de Desenvolvimento Científico e Tecnológico (CNPq) for grants and financial support, the Robert O. Bass Visiting Scientist Fund to the senior author when visiting Field Museum of Natural History, and ACSI Project (NSF DEB-0315963) for fund support to the junior author.

\section{References}

Abucarma, M. \& I. C. Martins-Santos. 2001. Karyotype and B chromosome of Rhamdia species (Pisces, Pimelodidae) endemic in the River Iguaçu basin. Cytologia, 66: 299-306.

Baumgartner, G., C. S. Pavanelli, D. Baumgartner, A. G. Bifi, T. Debona \& V. A. Frana. 2012. Peixes do baixo rio Iguaçu. Maringá, Eduem, 203p.

Bockmann, F. A. \& G. M. Guazzelli. 2003. Family Heptapteridae (Heptapterids). Pp. 406-431. In: Reis, R. E., S. O. Kullander \& C. J. Ferraris, Jr. (Orgs.). Check list of the freshwater fishes of South and Central America. Porto Alegre, Edipucrs.
Bookstein, F. L., B. Chernoff, R. L. Elder, J. M. Humphries, G. R. Smith \& R. F. Strauss. 1985. Morphometrics in evolutionary biology: the geometry of size and shape change, with examples from fishes. Philadelphia, Academy of Natural Sciences of Philadelphia, 277p. (Special publication/ Academy of Natural Sciences of Philadelphia, 15).

Ferraris, C. J., Jr. 2007. Checklist of catfishes, recent and fossil (Osteichthyes: Siluriformes), and catalogue of siluriform primary types. Zootaxa, 1418: 1-628.

Fowler, H. W. 1954. Os peixes de água doce do Brasil. Arquivos de Zoologia do Estado de São Paulo, 9: 1-400.

Garavello, J. C. 2005. Revision of genus Steindachneridion (Siluriformes: Pimelodidae). Neotropical Ichthyology, 3: 607-623.

Garavello, J. C., H. A. Britski \& C. H. Zawadzki. 2012. The cascudos of the genus Hypostomus Lacépède (Ostariophysi: Loricariidae) from the rio Iguaçu basin. Neotropical Ichthyology, 10: 263-283.

Garavello, J. C., C. S. Pavanelli \& H. I. Suzuki. 1997. Caracterização da ictiofauna do rio Iguaçu. Pp. 61-84. In: Agostinho, A. A. \& L. C. Gomes (Eds.). Reservatório de Segredo: bases ecológicas para o manejo. Maringá, Eduem.

Garavello, J. C. \& F. A. A. Sampaio. 2010. Five new species of genus Astyanax Baird \& Girard, 1854 from rio Iguaçu, Paraná, Brazil (Ostariophysi, Characiformes, Characidae). Brazilian Journal of Biology, 70: 847-865.

Garavello, J. C. \& O. A. Shibatta. 2007. A new species of the genus Pimelodus La Cépède, 1803 from the rio Iguaçu basin and a reappraisal of Pimelodus ortmanni Haseman, 1911 from the rio Paraná system, Brazil (Ostariophysi: Siluriformes: Pimelodidae). Neotropical Ichthyology, 5: 285-292.

Garcia, C., O. Moreira-Filho, L. A. C. Bertollo \& L. Centofante. 2003. B chromosomes and natural triploidy in Rhamdia sp. (Pisces, Siluriformes, Heptapteridae). Cytologia, 68: 403411.

Garcia, C., C. Oliveira \& L. F. Almeida-Toledo. 2010. Karyotypic evolution trends in Rhamdia quelen (Siluriformes, Heptapteridae) with considerations about the origin and differentiation of its supernumerary chromosomes. Genetics and Molecular Research, 9: 365-384.

Gosline, W. A. 1945. Catálogo dos Nematognathos de água doce da América do Sul e Central. Boletim do Museu Nacional, 33: 1-138.

Hammer, O., D. A. T. Harper \& P. D. Ryan. 2001. PAST: Paleontological Statistics Software Package for education and data analysis. Palaeontologia Electronica, 4:1-9.

Haseman, J. D. 1911. Some new species of fishes from the rio Iguassú. Annals of the Carnegie Museum, 7: 374-387.

Ibarra, M. \& D. J. Stewart. 1987. Catalogue of type specimens of recent fishes in Field Museum of Natural History. Fieldiana, 1377: 1-112.

Martinez, J. F., R. L. Lui, D. R. Blanco, J. B. Traldi, L. F. Silva, P. C. Venere, I. L. Souza \& O. Moreira-Filho. 2011. Comparative cytogenetics of three populations from the Rhamdia quelen species complex (Siluriformes, Heptapteridae) in two Brazilian hydrographic basins. Caryologia, 64: 121-128.

Mees, G. F. 1974. The Auchenipteridae and Pimelodidae of Suriname (Pisces, Nematognathi). Zoologische Verhandelingen, 132: 1-246.

Mise, F. T., L. F. C. Tencatt \& F. Souza. 2013. Ecomorphological differences between Rhamdia (Bleeker, 1858) populations from the Iguaçu River basin. Biota Neotropica, 13: 99-104. 
Moraes, V. P. O., S. S. Cereali, O. Froehlich \& A. L. Dias. 2007. Cytogenetic characterization of Rhamdia quelen (Siluriformes, Heptapteridae) from the Bodoquena Plateau, Mato Grosso do Sul, Brazil. Genetics and Molecular Research, 6: 627-633.

Perdices, A., E. Bermingham, A. Montilla \& I. Doadrio. 2002. Evolutionary history of the genus Rhamdia (Teleostei: Pimelodidae) in Central America. Molecular Phylogenetics and Evolution, 25: 172-189.

Severi, W. \& A. A. M. Cordeiro. 1994. Catálogo de peixes da bacia do rio Iguaçu. Curitiba, Instituto Ambiental do Paraná (IAP)/Deutsche Gessellschaft für Technische Zusammenarbeit, 118p.

Shibatta, O. A. \& J. C. Garavello. 1995. Uma nova espécie de Rhamdia Bleeker, 1858 (Siluriformes, Pimelodidae) do rio Iguaçu. P. B4. In: Encontro Brasileiro de Ictiologia, 11, 1995, Campinas, SP, Resumos... Campinas, SP, PUC, SBI.
Silfvergrip, A. M. C. 1996. A systematic revision of the Neotropical catfish genus Rhamdia (Teleostei, Pimelodidae). Stockholm, Stockholm University, 156p.

Wosiacki, W. B. \& J. C. Garavello. 2004. Five new species of Trichomycterus from the rio Iguaçu (rio Paraná basin), southern Brazil (Siluriformes: Trichomycteridae). Ichthyological Exploration of Freshwaters, 15: 1-16.

Submitted October 20, 2015

Accepted January 12, 2016 by Guillermo Ortí 